\section{Investigation of mineralogical composition and technological properties of conventional brick clays}

LÁszLó A. GÖMZE - Institute of Ceramics and Polymer Engineering, University of Miskolc $\cdot$ femgomze@uni-miskolc.hu

SERGEI N. KULKOV - Institute of Strength Physics and Materials Science SB RAS,

National Research Tomsk State University - kulkov@ms.tsc.ru

EMESE KUROVICS - Institute of Ceramics and Polymer Engineering, University of Miskolc - fememese@uni-miskolc.hu

ALES S. BUYAKOV - Institute of Strength Physics and Materials Science SB RAS, National Research Tomsk State University • alesbuyakov@gmail.com

SvetLana P. BUYAKOVA - Institute of Strength Physics and Materials Science of RAS, Tomsk State University - sbuyakova@ispms.ru

ALEXANDR Y BUZIMOV - Institute of Strength Physics and Materials Science SB RAS, National Research Tomsk State University • buzimov92@gmail.com

RóBERT GÉBER - Institute of Ceramics and Polymer Engineering,

University of Miskolc $\cdot$ femgeber@uni-miskolc.hu

MiralL V. GRIGORIEV - Institute of Strength Physics and Materials Science of RAS,

Tomsk Polytechnic University • grv@ispms.ru

IsTVÁN KOCSERHA - Institute of Ceramics and Polymer Engineering,

University of Miskolc • istvan.kocserha@uni-miskolc.hu

ALEKSEY S. KULKOV - Institute of Strength Physics and Materials Science SB RAS, National Research Tomsk State University

TAtIANA Yu. SABLINA - Institute of Strength Physics and Materials Science of RAS - sabtat@ispms.ru NikolaI L. SAVCHENKO - Institute of Strength Physics and Materials Science of RAS - savnick@ispms.ru IRINA N. SEVOSTYANOVA - Institute of Strength Physics and Materials Science of RAS - sevir@ispms.ru ANDREA SIMON - Institute of Ceramics and Polymer Engineering,

University of Miskolc - femandi@uni-miskolc.hu

Érkezett: 2018. 01. 15. " Received: 15. 01. 2018. " https://doi.org/10.14382/epitoanyag-jsbcm.2018.2

\section{Abstract}

In this research the layers of a Hungarian conventional brick clay deposit were examined both on material and mineralogical structures and compositions as well as on technological properties. During their examination the authors have found that the volumes of X-ray amorphous submicron and nano particles of the conventional brick clays do not influence on the dry sensitivity of the extruded and formed green products. The authors have found also a strong correlation between the X-ray amorphous nano particles of raw materials and the bending strengths of the sintered ceramics. As more the volumes of submicron and nano particles are in the conventional brick clays as higher are the bending strengths of the produced from them sintered ceramics.

Keywords: bending strength, bricks, clays, drying, minerals, roof tiles, shrinkage, X-ray diffraction

Tatiana Yu. SABLINA,

has PhD Education since 1989 at present she is working at the Tomsk State University and Institute of Strength Physics and Materials Science of the Russian Academy of Sciences in Tomsk.

Nikolai L. SAVCHENKO,

PhD Education: 1987: Tomsk Polytechnic Universityengineer.1991-1994: Institute of Strength Physics and Materials Science of the Russian Academy of Sciences in Tomsk - PhD student. 1995: PhD.degree from the Institute of Strength Physics and Materials Science of the Russian Academy of Sciences in Tomsk.

Irina N. SEVOSTYANOVA,

PhD Education: 1987: Tomsk Polytechnic Universityengineer.1993-1996: Institute of Strength Physics and Materials Science of the Russian Academy of Sciences in Tomsk - PhD student. 2001: PhD.degree from the Institute of Strength Physics and Materials Science of the Russian Academy of Sciences in Tomsk. Field of research: Structure and mechanical property of porous ceramics based zirconia and alumina.

Andrea SIMON,

is graduated in the University of Miskolc and has PhD since 2010. At present she is associate professor of the Department of Ceramics and Silicate Engineering (DCSE) in University of Miskolc (Hungary).
László A. GöMZE,

is establisher and professor of the Department of Ceramics and Silicate Engineering in the University of Miskolc, Hungary. He is author or coauthor of 2 patents, 6 books and more than 300 scientific papers. Recently, he is the chair of the International Organization Board of ic-cmtp5 the 5th International Conference on Competitive Materials and Technological Processes (2018).

Sergei N. KULKOV, is professor of the Tomsk State University and head of Department of Ceramics in the Institute of Strength Physics and Materials Science of the Russian Academy of Science since 1989. His research works are represented in 5 books, more than 150 articles, 18 patents and many International Symposiums and Conferences. At present he is head of department "Theory of Strength and Mechanic of Solids", member of "The American Ceramic Society" of "The APMI International" and the DYM AT Society (France).

Emese KUROVICS, is graduated in the University of Miskolc, Department of Ceramics and Silicate Engineering as a material engineer, where she actually continues her study as PhD student under supervision of Prof. L. A. Gömze.

Ales S. BUYAKOV, is graduated in the National Research Tomsk Polytechnic University, as an engineer and he actually continues his study as PhD student under supervision of Prof. S. N. Kulkov in the Institute of Strength Physics and Materials Science SB RAS

Svetlana P. BUYAKOVA, is Doctor of Sciences since 2008, full Professor since 2013. She is specialist in material sciences of ceramic and ceramic matrix composites based on oxides and carbides. She is author and co-author of more than 100 papers. Now, she is chief scientist in IS PMS RAS and professor in Tomsk State University and Tomsk Polytechnic University. Her teaching experience: Introduction to materials science, Fundamentals of materials engineering, Materials and their applications.

Alexandr Y. BUZIMOV, is graduated in the National Research Tomsk State University, as an engineer physic and he actually continues his study as PhD student under supervision of Prof. S. N. Kulkov in the Institute of Strength Physics and Materials Science SB RAS. is graduated in the University of Miskolc and has PhD since 2013. At present he is lecturer at the Institute of Ceramics and Polymer Engineering in University of Miskolc.

Mihail V. GRIGORIEV,

has PhD since 2007. At present time he is a post-doctoral fellow in Institute of Strength Physics and Materials Science of Siberian Branch of the Russian Academy of Science under guidance Prof. Kulkov.

István KOCSERHA,

is graduated in the University of Miskolc and has PhD since 2010. At present he is associate professor and chair of the Department of Ceramics and Silicate Engineering (DCSE) in University of Miskolc (Hungary). He is author or co-author of 35 articles and 1 Hungarian patent

Aleksey S. KULKOV, is physicist and has got PhD scientific degree at Tomsk State University in Russian Federation. A present he is working as research fellow at Institute of Strength Physics and Materials Science of the Russian Academy of Sciences in Tomsk. 


\section{Introduction}

In our days the conventional brick clays are playing very important role in production of ceramic bricks and roof tiles [1-14] but they are wildly used also in different segments of industry [15-17]. Their mineralogical composition, grain size distribution, moisture and specific surface are influencing very strong not only on color and quality of the final products but on the technological properties and parameters also [18-20]. There are several authors underpin that the drying sensitivity of the conventional brick clays depends on their grain sizes and specific surfaces, means as smaller the average grain size and higher the specific surface are as stronger the susceptibility of clays is to the drying sensitivity and drying cracks [21-24]. This option is one of the reasons that it is so important to analyze the mine layers before their exploitation to produce building ceramics like large borehole bricks or roof tiles.

It is obvious that the layers of the conventional brick clay deposits have formed during several thousand years. This circumstance is one of the reasons why they may have very different mineralogical, chemical, morphological and grain size structures depending on their position and location inside of the mined deposits and layers.

The aims of this research work to determine the mineral composition of the layers of a new clay deposit and their influence on the technological properties like extruding, drying and firing as well as shrinkages and bending strengths of the sintered products.

\section{Materials and experiments}

To determine the material structure, specific surface, mineralogical composition, extruding, drying and sintering properties of clay minerals of a new Hungarian quarry 9 mining holes were drilled in a square mesh structure in $15 \mathrm{~m}$ depth of each. The drilled out materials from each mined holes were divided by $5 \mathrm{~m}$ as $0-5 \mathrm{~m}, 6-10 \mathrm{~m}, 11-15 \mathrm{~m}$ and were crashed and mixed on a laboratory pan mill with 90rpm through 10 minutes. From each mixture by $100 \mathrm{~g}$ were taken for the material tests as scanning electron microscopy (SEM and EDAX), Langmuir and BET specific surface determination and X-ray diffraction. All the remaining clays were extruded on a KEMA-PVP 5/S extruder into cylindrical shape rods with diameter of $33 \mathrm{~mm}$. After extrusions each rods were cut on 7 specimens by 150 $\mathrm{mm}$ green lengths of each before drying, sintering and bending strength tests. In this research work are shown the results of material tests and examinations made on mixes of the 3 different layers taken from the central $\left(5^{\text {th }}\right)$ drilling hole.
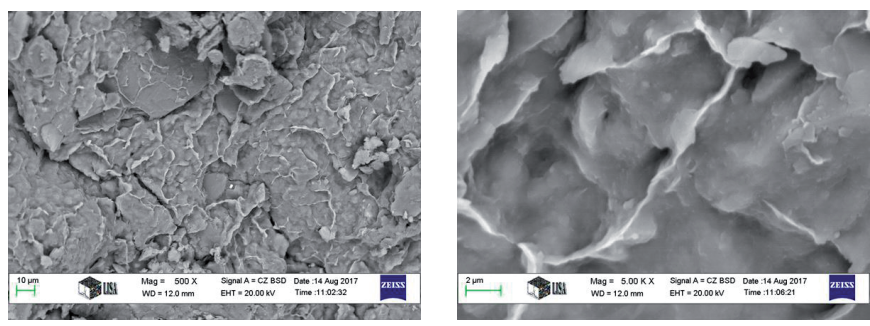

Fig 1. Material structure of clay mixture from layer 11-15m

1. ábra A 11-15m-es agyag réteg anyagszerkezete
The typical material structure and chemical composition of clay mixtures investigated with scanning electron microscopy and EDAX are shown in Figure 1 and Figure 2.

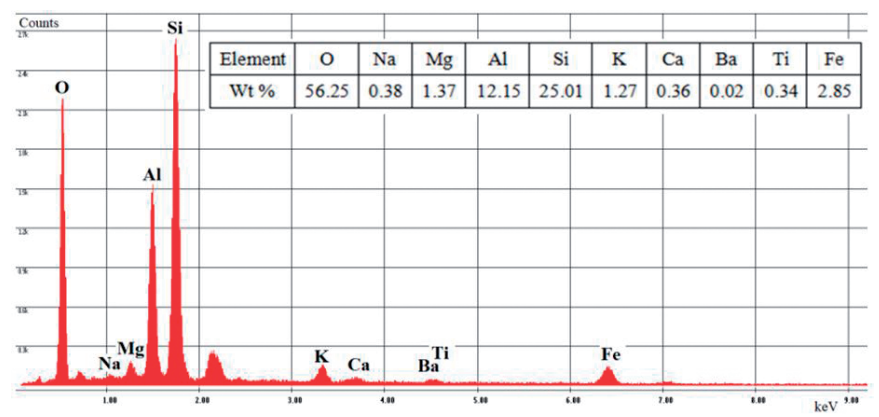

Fig 2. The surface chemical composition of clay mixture from layer $11-15 \mathrm{~m}$ 2. ábra A 11-15m-es agyag réteg kémiai összetétele

\section{Results and discussions}

The material samples taken from mixtures by $100 \mathrm{~g}$ of each were dried in a laboratory chamber-dryer at $85^{\circ} \mathrm{C}$ during 72 hours. After drying some part of them was used to determine specific surfaces and part of them for determine the mineral and chemical composition through X-ray diffraction. The Langmuir and BET specific surfaces were determined with instrument TriStar 3000 and the results are given in the Table 1.

\begin{tabular}{|c|c|c|c|c|}
\hline \multirow{2}{*}{ Layers } & \multirow{2}{*}{$\begin{array}{l}\text { Tested } \\
\text { mass }\end{array}$} & \multirow{2}{*}{$\begin{array}{l}\text { Langmuir, } \\
\text { m²/g }^{2}\end{array}$} & \multicolumn{2}{|c|}{ BET, $\mathrm{m}^{2} / \mathrm{g}$} \\
\hline & & & single & multi \\
\hline \multirow{2}{*}{$0-5 \mathrm{~m}$} & \multirow{2}{*}{$0.3096 \mathrm{~g}$} & 28.7347 & 19.1615 & 20.3931 \\
\hline & & 31.7419 & 21.3475 & 22.5983 \\
\hline \multirow{2}{*}{ 6-10 m } & \multirow{2}{*}{$0.4781 \mathrm{~g}$} & 29.5417 & 19.6578 & 20.9726 \\
\hline & & 32.1277 & 21.6153 & 22.9077 \\
\hline \multirow{2}{*}{$11-15 m$} & \multirow{2}{*}{$0.2686 \mathrm{~g}$} & 30.7266 & 20.4658 & 21.7865 \\
\hline & & 33.3207 & 22.4282 & 23.7279 \\
\hline
\end{tabular}

Table 1. The specific surfaces of the clay mineral mixtures taken from the 3 different layers of drilling 5

1. táblázat Az 5. furat 3 különböző rétegéböl vett agyagminták fajlagos felülete

The XRD diagrams of the layers are given in Figure 3 and the mineralogical and oxide compositions of the layers are given in Table 2 and Table 3.

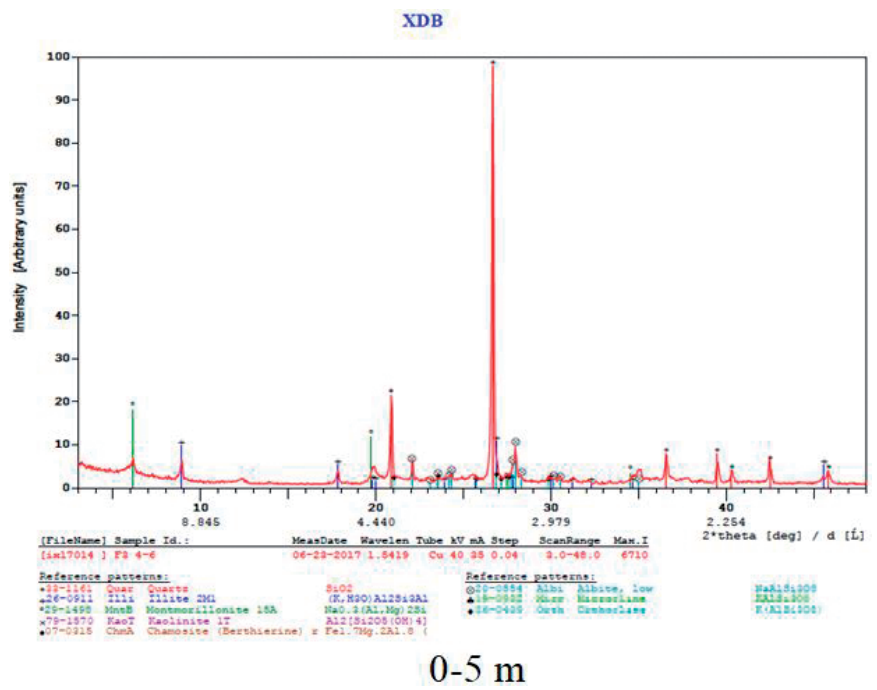


XDB

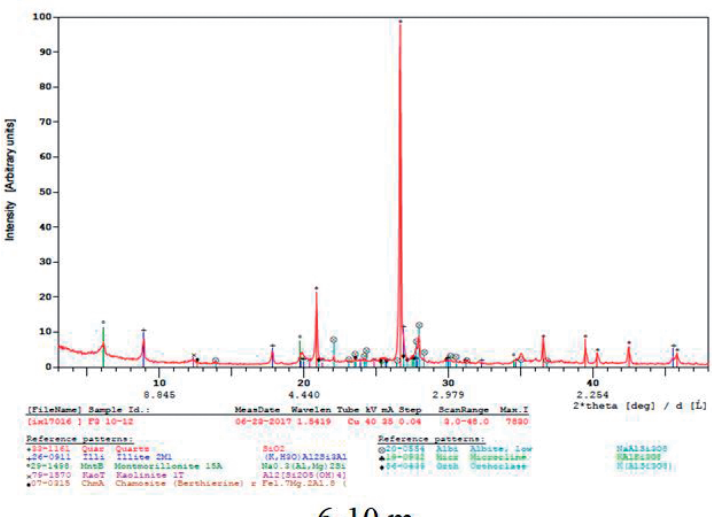

$6-10 \mathrm{~m}$

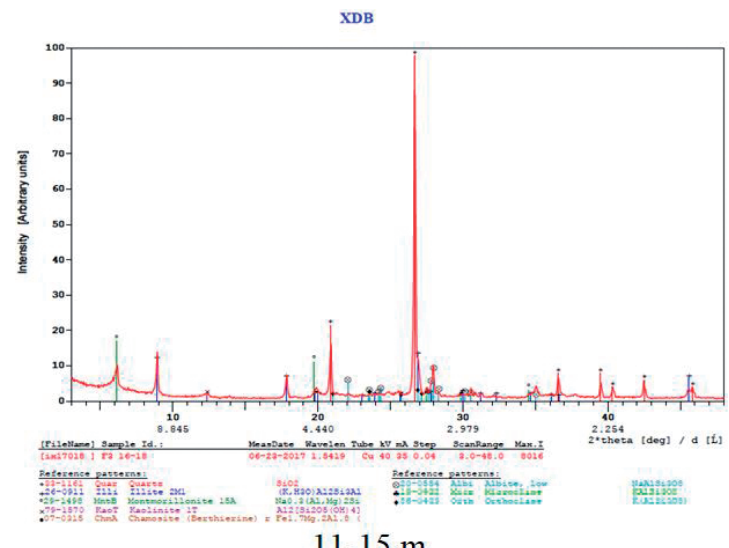

$11-15 \mathrm{~m}$

Fig 3. The X-ray diagram of materials taken from the 3 different layers of the drilling $5^{\text {th }}$ 3. ábra Az 5. furat 3 különbözö rétegének a röntgendiffraktogramja

\begin{tabular}{|c|c|c|c|c|}
\hline & Minerals & $0-5 \mathrm{~m}$ & $\begin{array}{c}\text { 6-10 } \\
\mathrm{m}\end{array}$ & $\begin{array}{c}11-15 \\
m\end{array}$ \\
\hline quartz & $\mathrm{SiO}_{2}$ & 28 & 30 & 30 \\
\hline illite & {$\left[\mathrm{K}\left(\mathrm{H}_{3} \mathrm{O}\right)^{+}\right] \mathrm{Al}_{2}\left[\mathrm{SiO}_{3} \mathrm{AlO}_{10}\right](\mathrm{OH})_{2}$} & 14 & 15 & 18 \\
\hline montmorilonite & $\begin{array}{c}(0,5 \mathrm{Ca}, \mathrm{Na})_{0,7}\left(\mathrm{Mg}_{0,7} \mathrm{Al}_{3,3}\right) \\
{\left[\left(\mathrm{Si}_{8} \mathrm{O}_{20}\right)(\mathrm{OH})_{4}\right]}\end{array}$ & 12 & 8 & 12 \\
\hline kaolinite & $\mathrm{Al}_{2} \mathrm{Si}_{2} \mathrm{O}_{5}(\mathrm{OH})_{4}$ & 1 & 3 & 2 \\
\hline chamosite & $\left(\mathrm{Fe}^{2+}, \mathrm{Mg}\right)_{5} \mathrm{Al}\left(\mathrm{AlSi}_{3} \mathrm{O}_{10}\right)(\mathrm{OH})_{8}$ & 2 & 3 & 2 \\
\hline albite & $\mathrm{NaAlSi}_{3} \mathrm{O}_{8}$ & 13 & 16 & 12 \\
\hline microcline & $\mathrm{KAISi}_{3} \mathrm{O}_{8}$ & 2 & 2 & 2 \\
\hline orthoclase & $\mathrm{KAISi}_{3} \mathrm{O}_{8}$ & 3 & 3 & 3 \\
\hline XRD-amorphous & - & 25 & 20 & 19 \\
\hline
\end{tabular}

Table 2. The mineral composition of the layers from the drilling $5^{\text {th }}$ 2. táblázat Az 5. furat rétegeinek ásványi összetétele

\begin{tabular}{lccc}
\multicolumn{1}{c}{ Oxides } & $\mathbf{0 - 5} \mathbf{~}$ & $\mathbf{6 - 1 0 ~} \mathbf{m}$ & $\mathbf{1 1 - 1 5 ~} \mathbf{m}$ \\
$\mathbf{F e}_{2} \mathbf{O}_{3} \%$ & 0.84 & 1.26 & 0.84 \\
\hline $\mathbf{K}_{2} \mathbf{O} \%$ & 2.17 & 2.27 & 2.55 \\
\hline $\mathbf{S i O}_{2} \%$ & 55.08 & 58.2 & 58.67 \\
\hline $\mathbf{A l}_{2} \mathbf{O}_{3} \%$ & 11.35 & 12.82 & 13.08 \\
\hline $\mathbf{M g O} \%$ & 1.32 & 0.91 & 1.32 \\
\hline $\mathbf{N a}_{2} \mathbf{O} \%$ & 1.83 & 2.09 & 1.71 \\
\hline $\mathbf{H}_{2} \mathbf{O} \%$ & 2.46 & 2.54 & 2.87 \\
\hline $\mathbf{L O I} \%$ & 2.41 & 2.46 & 2.82
\end{tabular}

Table 3. The oxides composition of the layers from the drilling $5^{\text {th }}$ 3. táblázat Az 5. furat rétegeinek oxidos összetétele
Analyzing the mineralogical composition determined by $\mathrm{X}$-ray diffraction we can see that total volumes of clay minerals are more than $25 \mathrm{~m} \%$ which means that this mined raw material is applicable to produce good quality ceramic bricks and roof tiles using plastic forming technology like extrusion. At the same time the ratios of the X-ray amorphous particles are higher than $15 \mathrm{~m} \%$ in each case. Because of the large volume of the X-ray amorphous submicron and nano particles after the sintering will be formed a nano size porous structure that will make the produced bricks and tiles frost resistant [25].

After the extrusion the 21 pieces of cylindrical rods with green lengths of $150 \mathrm{~mm}$ were dried in open air at room temperature of about $25-30^{\circ} \mathrm{C}$ and their diameters, lengths and weights were measured by 1 hour in the first 3 hours and after by 2 hours. The results of mass and volume losses are presented in Bourry diagrams in Figure 4.
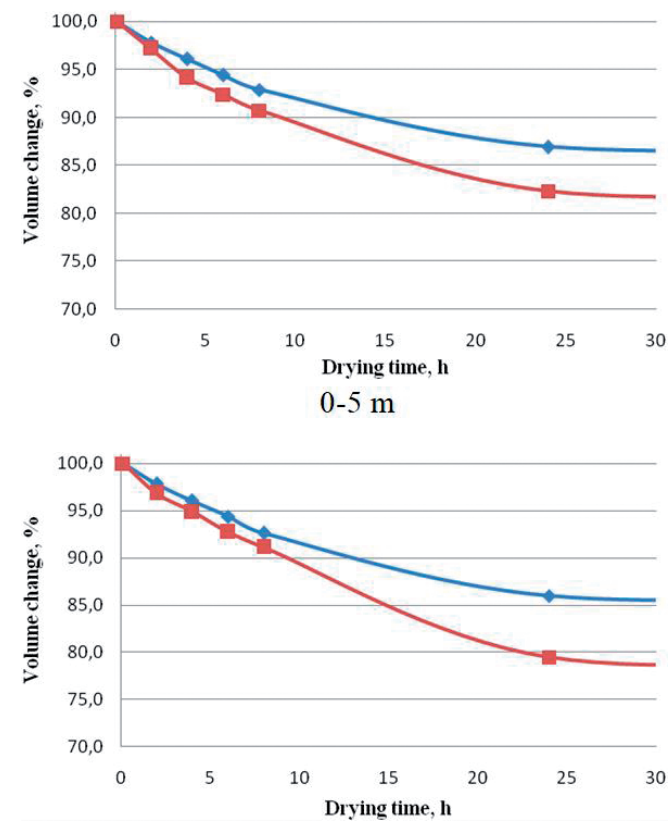

$6-10 \mathrm{~m}$

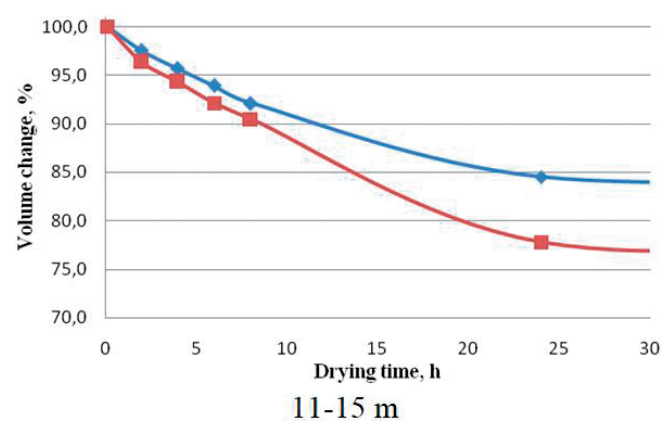

Fig 4. Bourry diagrams (volume and mass losses) during drying of the raw material mixtures of the 3 different layers

4. ábra A 3 különböző agyagréteg keverék száradási Bourry diagramja (térfogat és tömegveszteség)

There are huge number of literature which are studied and described the drying properties and drying shrinkage of the conventional brick clays. Most of them [1-4, 21-24 and 26-29] underpin that when in conventional brick clays the particles with $2 \mathrm{~mm}$ or less diameters are more than $15-20 \mathrm{~m} \%$ the extruded products will be inclined to formation of drying 
cracks because of the too fine grain structure. During the drying we did not find any cracks or microcraks not on the surfaces and nor in the cross-section of the extruded ceramic rods in spite that the studied brick clays have $19-25 \mathrm{~m} \%$ of particles with nano sizes. This means that increment of fine particles in the conventional brick clays does not increase the drying sensitivity of the extruded and plastic formed ceramic items. So the appearances of cracks during drying must be explained with incorrect forming pressures and residual stresses inside of the body after extrusion and pressing and not with the fine grain size structures.

After drying the 21 pieces of the cylindrical rod specimens were sintered in an electrical chamber kiln with heating rate of $60^{\circ} \mathrm{C}$ /hour up to $950^{\circ} \mathrm{C}$ and kept at this temperature during 2 hours and after the heating system was switched off. The volumetric and mass losses of drying and firing together are shown in Fig. 5 and Table 4.
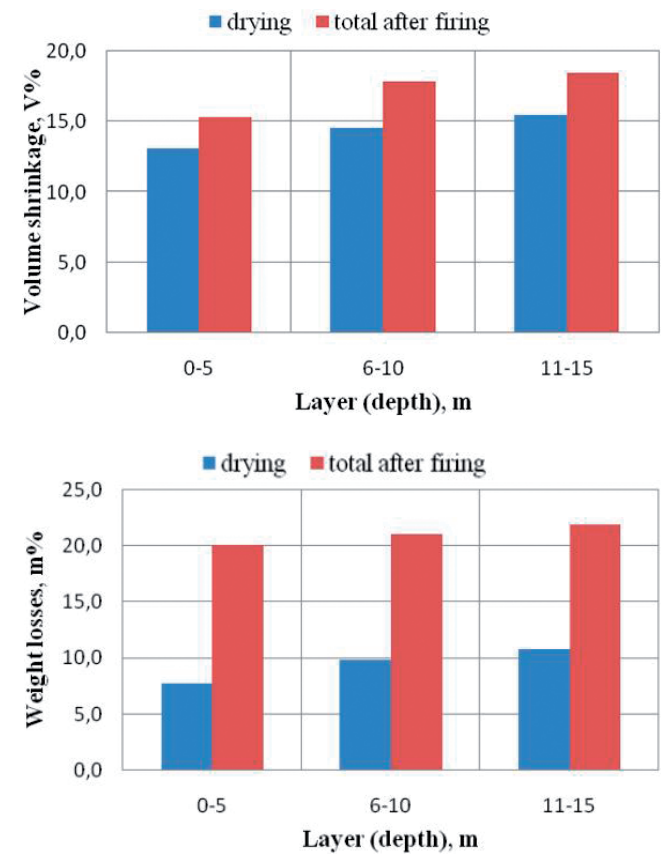

Fig. 5. The volumetric and mass losses of drying and total after firing 5. ábra A száradás és az égetés utáni teljes térfogat-és a tömegváltozás

Generally the ceramics produced from conventional brick clays and sintered at less than $950-1000^{\circ} \mathrm{C}$ which is relatively low temperature for formation mullite and other mechanically strength crystals. Because of this circumstance the sintered cylindrical rod specimens were tested also on 3 point bending strength (Table 4).

\begin{tabular}{cccccc}
$\begin{array}{c}\text { Depth of } \\
\text { drilling, } \\
\mathbf{m}\end{array}$ & $\begin{array}{c}\text { Volume shrinkage, } \% \\
\text { total } \\
\text { after } \\
\text { firing }\end{array}$ & $\begin{array}{c}\text { The weight loss, } \% \\
\text { dry }\end{array}$ & $\begin{array}{c}\text { 3 point } \\
\text { total } \\
\text { after } \\
\text { firing }\end{array}$ & $\begin{array}{c}\text { sending } \\
\text { strength, } \\
\mathbf{M P a}\end{array}$ \\
\hline $0-5$ & 13.07 & 15.32 & 7.80 & 20.11 & 15.87 \\
\hline $6-10$ & 14.54 & 17.85 & 9.90 & 21.10 & 12.05 \\
\hline $11-15$ & 15.51 & 18.45 & 10.79 & 21.92 & 12.07 \\
Table 4. & $\begin{array}{l}\text { The volumetric and mass losses of drying and total after firing and the 3 point } \\
\text { bending strength of specimens } \\
\text { 4. táblázat száradás és az égetés utáni teljes térfogat-illetve tömegváltozás és a } \\
\text { próbatestek hárompontos hajlitószilárdsága }\end{array}$
\end{tabular}

The 3 point bending strength test gave relatively high values which means that the conventional clay minerals from this new mine can be perfectly used for production ceramic roof tiles with high quality. Analyzing the reasons of this relatively good mechanical bending strength the authors could not find a convincing correlation between the bending strength and quartz content but a very good correlation have been found between the bending strength and volumes of XRD amorphous fine particles in the conventional brick clay raw material (Figure 6). So it can be stated that using conventional brick clays the bending strength of the sintered products will as higher as more X-ray amorphous nano particles are in the minerals.

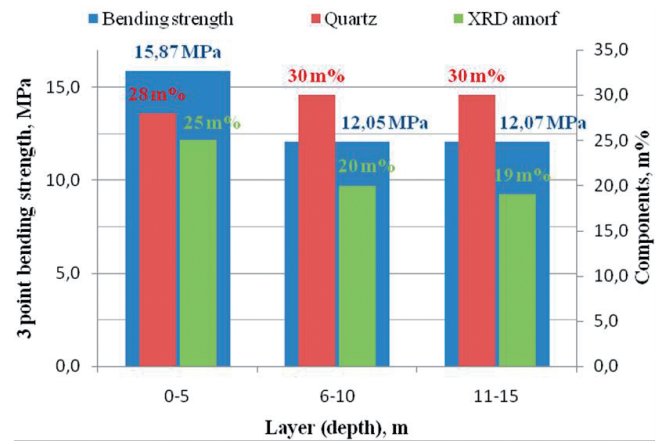

Fig 6. Bending strength [MPa], quartz and X-ray amorphous nano particles ratio [ $\mathrm{m} \%]$ of specimens made and sintered from the clays of the different layers 6. ábra A különbözö rétegekböl készült, szinterelt próbatestek hajlitószilárdsága [MPa], kvarc és röntgen amorf aránya [m\%]

\section{Conclusion}

The most important conclusion of the present research work is that the examined clay deposit is applicable for production building ceramic items like wall bricks and roof tiles. At the same time submicron and nano particles of the conventional clays are not reason of the micro and macro cracks on surface and in body during drying the extruded and pressed from them products.

The strong correlation was founded between the bending strength of the sintered cylindrical ceramic rods and the volume of the $\mathrm{X}$-ray amorphous submicron and nano particles. As more the volumes of submicron and nano particles are in the conventional brick clays as higher are the bending strengths of the produced from them sintered ceramics.

\section{Acknowledgements}

This work was carried out with partial support of project \#14.584.21.0026 (RFMEFI58417X0026).

The authors thank to IGREX Engineering Service Ltd for support and finance this research.

\section{References}

[1] Péter, Gyula (1974): Machine of Ceramic Industry, Müszaki Könyvkiadó, Budapest (in Hungarian)

[2] Tamás, Ferenc (1982): Handbook of Silicate Industry, Müszaki Könyvkiadó, Budapest ISBN 963-10-4365-7 (in Hungarian)

[3] Carter, C. Barry - Norton, M. Grant (2007): Ceramic Materials Science and Engineering, Springer, New York, e-ISBN-13 978-0-387-46271-4 
[4] Sarani, N. A. - Kadir, A. A. (2013): Advenced Materials Research 690693 pp 919

https://doi.org/10.4028/www.scientific.net/AMR.690-693.919

[5] Kadir, A. A. - Hinta, H. - Sarani, N. A. (2015): ARPN Journal of Engineering and Applied Science 10 (15) 6289 ISSN 1819-6608

[6] Aouba, L. - Coutand, M. - Perrin, B. - Lemercier, H. (2015): Journal of Building Physics https://doi.org/10.1177/1744259115571078

[7] Kalmár, J. - Kocsis-Buruzs, G. (2016): Építőanyag-JSBCM 68 (4) 105 http://dx.doi.org/10.14382/epitoanyag-jsbcm.2016.18

[8] Munoz, V. P. - Morales, M. P. - Letelier, G. V. - Mendívil G., M. A. (2016): Construction and Building Materials 125241 http://dx.doi.org/10.1016/j.conbuildmat.2016.08.024

[9] Korah, L. V. - Nigay, P-M. - Cutard, T. - Nzihou, A. - Thomas, S. (2016): Construction and Building Materials 125654 http://dx.doi.org/10.1016/j.conbuildmat.2016.08.094

[10] Tantawy, M. A. - Mohamed, R. S. A. (2017): Applied Clay Science $138114 \mathrm{http}: / / \mathrm{dx}$. doi.org/10.1016/j.clay.2017.01.005

[11] Safeer, A. - Yassen, I. - Raz, M. (2017): Boletin de la Sociedad Espanola de Ceramica y Vidrio 56 (3) http://dx.doi.org/10.1016/j.bsecv.2017.02.001

[12] Nigay, P-M. - Sani, R. - Cutard, T. - Nzihou, A. (2017): Materials Science and Engineering A $708 \mathrm{http} / / / \mathrm{dx}$. doi.org/10.1016/j.msea.2017.09.131

[13] Sveda, M. - Sokolar, R. - Janík, B. - Stefunková, Z. (2017): Materials Science 23 (2) http://dx.doi.org/10.5755/j01.ms.23.2.15103

[14] Dominguez, D. - Munoz, V. P. - Munoz, V. L. (2017): Materiales de Construcccón 67 (328) 133 http://dx.doi.org/10.3989/mc.2017.03316

[15]Dondi, M. - Iglesias, C. - Dominguez, E. - Guarini, G. - Raimondo, M. (2008): Applied Clay Science 40143

https://doi.org/10.1016/j.clay.2007.07.003

[16] Sperberga, I. - Sedmale, G. - Stinkulis, G. - Zeila, K. - Ulme, D. (2011): IOP Conf. Ser.: Mater. Sci. Eng. 18222027 https://doi.org/10.1088/1757-899X/18/22/222027

[17] Khramchenkov, M. G. - Usmanov, R. M. (2017): Építőanyag-JSBCM 69 (4) $110 \mathrm{http} / / / \mathrm{dx}$.doi.org/10.14382/epitoanyag-jsbcm.2017.19

[18] Tóth, K. - Bálint, P. - Bakos, J. (1968): Th e Examination of Drying Sensitivity of Hungarian Ceramic Raw Materials by Alviset's Method; Építőanyag 20 (8) 302

[19]Bálint, P.- Tóth, K. (1973): Analyse einer Vielzahl von ZiegeltonKenndaten durch Datenverarbeitung mittels Computer; Tonindustrie Ztg. 97 (5) 122

[20]Bálint, P.- Szőke, B. - Juhász, J. - Skorecz, T. (1981): Equilibrium moisture diagrams for the drying of clays; Ceramics International, 7 (1) 35

[21]Sopronyi, Gábor (1978): Testing of Drying Sensitivity be the „Barelattograph”; Építőanyag, 30 (6) 219

[22] Vértesffy, K. - Verdes, S. (1985): Connexion between Drying and Physical Chemical Characteristics of Ceramic Raw Materials and Bodies; Építőanyag, 37 (7) 193

[23] Junge, K. - Tretan, A. - Specht, E. (2007): Energy expenditure for drying of green bricks in chamber dryers; Zi-ANNUAL 2007., p. 25-38; by Müller W. and Fisher A.; Bauverlag BV GmbH; Gütersloh
[24]Junge, K. - Tretan, A. - Specht, E. (2008): Drying of green bricks Material-related principles, kinetics and energetics; Zi-ANNUAL 2008. p. 28-71. Edited by Fischer A., Bauverlag BV GmbH, Gütersloh

[25] Gömze, L. A. - Gömze, L. N. (2008): Építőanyag-JSBCM 60 (4) 102 http://dx.doi.org/10.14382/epitoanyag-jsbcm.2008.16

[26] Aungatichart, P. - Wada, S. (2009): Correlation between Bigot and Ratzenberger drying sensitivity indices of red clay from Ratchaburi province (Thailand) Applied Clay Science 43 (2) 182 http://dx.doi.org/10.1016/j.clay.2008.08.001

[27] Aksu, I. - Bazilevskaya, E. - Karpyn, Z. T. (2015): GeoResJ 71 http://dx.doi.org/10.1016/j.grj.2015.02.003

[28]Christopher (2017): Lenthall Destroying the structure of halloysite clay through oven drying, 6th International Young Geotechnical Engineers' Conference (iYGEC6)

[29]Haluk, Celik (2017): Technological characterization and comparison of two ceramic clays used for manufacturing of traditional ceramic products in Turkey, Madencilik 56 (4) 137

Ref.:

Gömze, László A.- Kulkov, Sergei N.- Kurovics, Emese- Buyakov, Ales S.- Buyakova, Svetlana P.- Buzimov, Alexandr Y.Géber, Róbert- Grigoriev, Mihail V.- Kocserha, IstvánKulkov, Aleksey S.- Sablina, Tatiana Yu.- Savchenko, Nikolai L.- Sevostyanova, Irina N. - Simon, Andrea: Investigation of mineralogical composition and technological properties of conventional brick clays

Építỏanyag - Journal of Silicate Based and Composite Materials, Vol. 70, No. 1 (2018), 8-12. p.

https://doi.org/10.14382/epitoanyag-jsbcm.2018.2

Hagyományos téglaagyagok ásványi összetételének és technológiai tulajdonságainak vizsgálata Jelen kutatás során hagyományos, magyarországi agyagbánya furat rétegeit vizsgálták a technológiai tulajdonságok, valamint az anyag-, és ásványi szerkezet alapján. A szerzốk megállapították, hogy a hagyományos téglaagyagok röntgenamorf, szubmikron és nanoméretũ részecskéinek mennyisége nincs hatással az extrudált nyers termékek repedésérzékenységére. A szerzôk erôs kapcsolatot találtak a nyersanyag röntgenamorf tartalma és a szinterelt kerámia hajlítószilárdsága között. Minél nagyobb arányban tartalmaz a hagyományos téglaagyag szubmikron és nanoméretú részecskéket, annál magasabb lesz a belôle készült, égetett kerámia termék hajlítószilárdsága.

Kulcsszavak: agyag, ásványok, cserép, hajlítószilárdság, száradás, tégla, XRD, zsugorodás

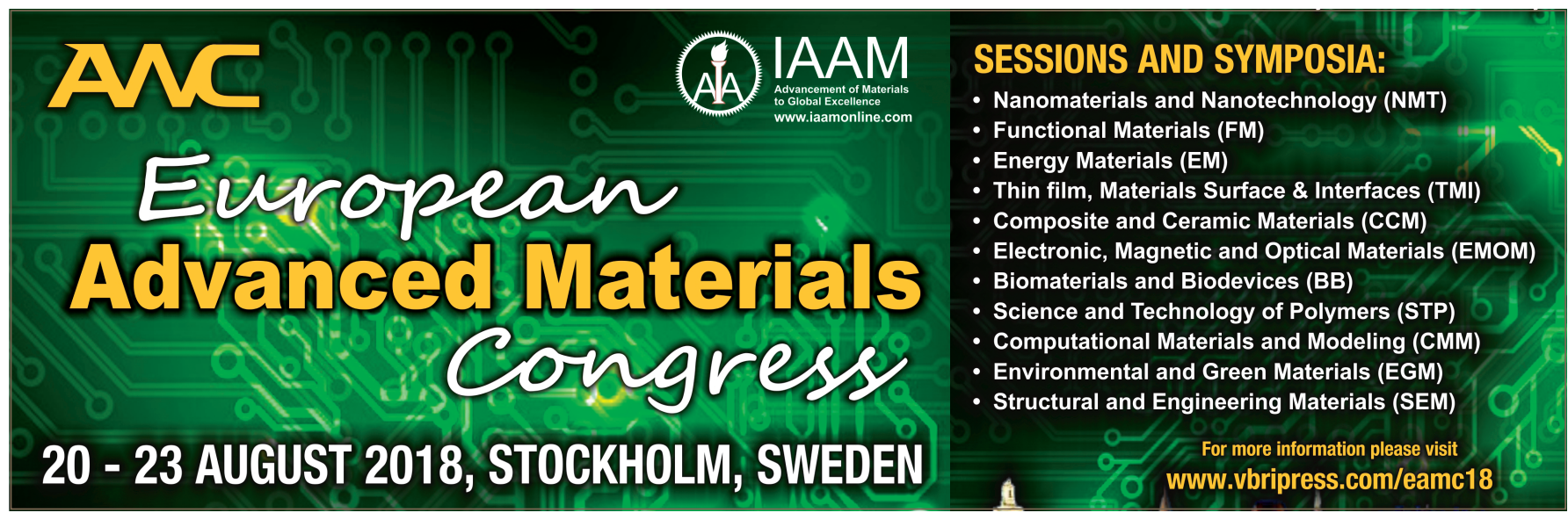

